\title{
Adherence to the ESC heart failure treatment guidelines in Spain: ESC Heart Failure Long-Term Registry
}

Adecuación en España a las recomendaciones terapéuticas de la guía de la ESC sobre insuficiencia cardiaca: ESC Heart Failure Long-term Registry

María G. Crespo-Leiro, ${ }^{\mathrm{a}}$ Javier Segovia-Cubero, ${ }^{\mathrm{b}}$ José González-Costello, ${ }^{\mathrm{c}}$ Antoni Bayes-Genis, ${ }^{\mathrm{d}}$ Silvia López-Fernández, ${ }^{\mathrm{e}}$ Eulàlia Roig, ${ }^{\mathrm{f}}$ Marisa Sanz-Julve, ${ }^{\mathrm{g}}$ Carla Fernández-Vivancos, ${ }^{\mathrm{h}}$ Manuel de Mora-Martín, ${ }^{\mathrm{i}}$ José Manuel García-Pinilla, ${ }^{\mathrm{j}}$ Alfonso Varela-Román, ${ }^{\mathrm{k}}$ Luis Almenar-Bonet, ${ }^{1}$ Antonio Lara-Padrón, ${ }^{\mathrm{m}}$ Luis de la Fuente-Galán, ${ }^{\mathrm{n}}$ Juan Delgado-Jiménez, ${ }^{\circ}$ on behalf of the project research team.

\footnotetext{
${ }^{a}$ Unidad de Insuficiencia Cardiaca y Trasplante, Servicio de Cardiología, Instituto de Investigación Biomédica de A Coruña (INIBIC), Complexo Hospitalario Universitario de A Coruña (CHUAC), SERGAS, Universidade da Coruña (UDC), A Coruña, Spain

${ }^{b}$ Unidad de Insuficiencia Cardiaca Avanzada, Trasplante e Hipertensión Pulmonar, Servicio de Cardiología, Hospital Universitario Puerta de Hierro, Majadahonda, Madrid, Spain

${ }^{c}$ Unidad de Insuficiencia Cardiaca Avanzada y Trasplante, Servicio de Cardiología, Hospital Universitari de Bellvitge-IDIBELL, L'Hospitalet de Llobregat, Barcelona, Spain

${ }^{d}$ Servicio de Cardiología, Hospital Universitario Germans Trias i Pujol, Badalona, Barcelona, Spain

${ }^{e}$ Unidad de Insuficiencia Cardiaca, Servicio de Cardiología, Hospital Universitario Virgen de las Nieves, Granada, Spain

${ }^{f}$ Unidad de Insuficiencia Cardiaca y Trasplante, Servicio de Cardiología, Hospital de la Santa Creu i Sant Pau, Barcelona, Spain

${ }^{g}$ Unidad de Insuficiencia Cardiaca Avanzada y Trasplante, Servicio de Cardiología, Hospital Universitario Miguel Servet, Zaragoza, Spain

${ }^{h}$ Servicio de Cardiología, Hospital Universitario Virgen Macarena, Seville, Spain

${ }^{i}$ Unidad de Gestión del Corazón y Enfermedades Cardiovasculares, Servicio de Cardiología, Hospital Regional

Universitario Carlos Haya, Málaga, Spain

${ }^{j}$ Unidad de Insuficiencia Cardiaca y Cardiopatías Familiares, Área de Gestión Clínica del Corazón, Hospital

Universitario Virgen de la Victoria, Málaga, Spain

${ }^{k}$ Servicio de Cardiología, Hospital Clínico Universitario Santiago de Compostela, Santiago de Compostela, A Coruña, Spain

${ }^{l}$ Unidad de Insuficiencia Cardiaca y Trasplante, Servicio de Cardiología, Hospital Universitario y Politécnico La $\mathrm{Fe}$, Valencia, Spain

${ }^{m}$ Servicio de Cardiología, Hospital Universitario de Canarias, La Laguna, Santa Cruz de Tenerife, Spain

${ }^{n}$ Unidad de Insuficiencia Cardiaca y Trasplante, Servicio de Cardiología, Hospital Clínico Universitario de Valladolid, Valladolid, Spain

${ }^{o}$ Unidad de Insuficiencia Cardiaca y Trasplante, Servicio de Cardiología, Hospital Universitario 12 de Octubre, Madrid, Spain
} 


\begin{abstract}
Introduction and objectives. To estimate the percentage of heart failure patients in Spain that received the European Society of Cardiology recommended treatments, and in those that did not, to determine the reasons why.

Methods. The study included 2834 consecutive ambulatory patients with heart failure from 27 Spanish hospitals. We recorded general information, the treatment indicated, and the reasons why it was not prescribed in some cases. In patients who met the criteria to receive a certain drug, true undertreatment was defined as the percentage of patients who, without justification, did not receive the drug.

Results. In total, $92.6 \%$ of ambulatory patients with low ejection fraction received angiotensin converting enzyme inhibitors or angiotensin receptor blockers, $93.3 \%$ beta-blockers, and $74.5 \%$ mineralocorticoid receptor antagonists. The true undertreatment rates were $3.4 \%, 1.8 \%$, and $19.0 \%$, respectively. Target doses were reached in $16.2 \%$ of patients receiving angiotensin converting enzyme inhibitors, $23.3 \%$ of those with angiotensin receptor blockers, $13.2 \%$ of those prescribed beta-blockers, and $23.5 \%$ of those with mineralocorticoid receptor antagonists. Among patients who could benefit from ivabradine, $29.1 \%$ received this drug. In total, $36 \%$ of patients met the criteria for defibrillator implantation and $90 \%$ of them had received the device or were scheduled for implantation, whereas 19.6\% fulfilled the criteria for resynchronization therapy and $88.0 \%$ already had or would soon have the device. In patients who met the criteria, but did not undergo device implantation, the reasons were not cost-related.

Conclusions. When justified reasons for not administering heart failure drugs were taken into account, adherence to the guideline recommendations was excellent. Exclusive use of the percentage of treated patients is a poor indicator of the quality of healthcare in heart failure. Measures should be taken to improve the attainment of optimal dosing in each patient.
\end{abstract}

\title{
Resumen
}

Introducción y objetivos. Estimar la proporción de pacientes con insuficiencia cardiaca atendidos en España que reciben los tratamientos recomendados por la Sociedad Europea de Cardiología y razones de que no los reciban, en su caso.

Métodos. Se incluyó a 2.834 pacientes ambulatorios consecutivos con insuficiencia cardiaca de 27 hospitales españoles. Se recogió información general, tratamiento indicado y causas de que no lo recibiera, en su caso. De los pacientes que cumplen criterios para recibir tratamiento, infratratamiento real es la proporción que, sin justificación, no lo recibe.

Resultados. El 92,6\% de los pacientes ambulatorios con fracción de eyección reducida recibieron inhibidores de la enzima de conversión de la angiotensina o antagonistas del receptor de la angiotensina II; el 93,3\%, bloqueadores beta y el 74,5\%, antagonistas del receptor mineralocorticoideo. El infratratamiento real es del 3,4, el 1,8 y el 19,0\% respectivamente. Alcanzan dosis objetivo de inhibidores de la enzima de conversión de la angiotensina el 16,2\% de los pacientes; de antagonistas de los receptores de la angiotensina II, el 23,3\%; de bloqueadores beta, el 13,2\% y de antagonistas del receptor mineralocorticoideo, el 23,5\%. El 29,1\% de los pacientes que podrían beneficiarse de ivabradina la reciben; el 36\% cumple criterios para implantar desfibrilador; de ellos, el $90 \%$ lo tienen ya implantado o programado; las cifras correspondientes en resincronización son el 19,6 y el 88,0\%; el porcentaje restante no se debe a causas económicas.

Conclusiones. Considerando razones justificadas para no administrar fármacos a estos pacientes, el cumplimiento de las guías es excelente. Utilizar solo la proporción de pacientes tratados es un mal indicador de calidad de la asistencia en insuficiencia cardiaca. Es necesario introducir medidas que mejoren el logro de la dosis óptima para cada paciente.

\section{Keywords}

Heart failure; Registry; Clinical practice guidelines; Treatment; Implantable defibrillator; Cardiac resynchronization therapy

\section{Palabras clave}

Insuficiencia cardiaca; Registro; Guías de práctica clínica; Tratamiento; Desfibrilador implantable; Terapia de resincronización cardiaca

\section{Abbreviations}

ACEI, angiotensin-converting enzyme inhibitors; ARB, angiotensin receptor blockers; BB, beta-blockers; EF, ejection fraction; HF, heart failure; MRA, mineralocorticoid receptor antagonists 


\section{INTRODUCTION}

Heart failure (HF) is a persistent health problem that places a significant burden on the health system and society in general and is anticipated to increase in the future. ${ }^{1}$

Certain treatments for this condition, some of which have been recently implemented, ${ }^{2,3}$ have proven effective for reducing HF events, particularly those leading to rehospitalization. Nonetheless, the incorporation of these advances in clinical practice tends to be slow. As a result, several studies investigating $\mathrm{HF}^{4,5}$ and other conditions ${ }^{6,7}$ have reported a discrepancy between the accepted approaches published in clinical practice guidelines and the activity seen in regular clinical practice. With regard to $\mathrm{HF}$, the gap between recommendations and what is done in clinical practice is much smaller now than in previous years, after justified reasons for not administering a recommended therapy have been taken into account. ${ }^{8}$

The European Society of Cardiology (ESC) has developed an HF registry, the ESC Heart Failure Long-Term Registry, ${ }^{8}$ to which Spain makes a prominent contribution, with $28.4 \%$ of all patients included in Europe (3536 of 12 440). This registry provides a good opportunity to evaluate whether the treatment of hospitalized and ambulatory HF patients in Spain is performed in accordance with the European recommendations. 3,9

Thus, the primary aim of this study was to estimate the percentage of HF patients attended in Spain who received the treatments recommended in the 2012 ESC guidelines, and, in those who did not, to determine the reasons why.

\section{METHODS}

\section{Study Design and Centers}

The ESC Heart Failure Long-Term Registry registry is a prospective, multicenter observational study performed in HF patients attending 211 cardiology centers in 21 ESC member countries in Europe and the Mediterranean area, including Spain.

The aim of ESC Heart Failure Long-Term Registry is to describe the clinical epidemiology of ambulatory and hospitalized patients with HF and to determine the diagnostic and therapeutic processes (including the organization of programs for HF management) applied in these patients over Europe as a whole and in the Mediterranean countries.

The registry was designed within the EORP (EURObservational Research Program) of the European Heart House of the ESC, and is coordinated by the EORP, which provides support to the related committees, national coordinators, and participating centers. ${ }^{10}$ Data are entered in a common electronic database that limits inconsistencies and errors and provides online help for key variables. Each center has access to its own data and each national coordinator has access to the data from all participating centers in that country.

The number of centers participating in each country was determined according to the size of the population. Attempts were made to have a balanced geographical representation while taking into account the differing care levels of the cardiology departments treating HF patients. Centers were selected (Appendix) through each country's national cardiology society and HF section, as established for EORP registries and surveys. ${ }^{11}$ 


\section{Patients}

On 1 day of the week over the 12 months of the inclusion period (April 2012-April 2013), each center included all $\mathrm{HF}$ patients older than 18 years attending the outpatient clinic and all those hospitalized on the same day for acute HF (either de novo HF or decompensation of a previous acute HF) with an intravenous therapy requirement (inotropic agents, vasodilators, or diuretics). Data collection was performed according to the criteria of the principal investigator of each center, and was usually carried out by personnel with no clinical activity assigned to the project.

A follow-up visit was scheduled at 1 year, either by personal interview or telephone contact (the data are not presented in this article). The present report includes only the ambulatory patients (chronic HF) recorded in the registry. In this population, the most robust recommendations in the 2012 ESC guidelines are for patients with HF and low ejection fraction (EF). An analysis was performed to determine whether these patients received the treatments recommended in the guidelines, specifically angiotensin-converting enzyme inhibitors (ACEI)/angiotensin receptor blockers (ARB), mineralocorticoid receptor antagonists (MRA), and ivabradine. Furthermore, the investigators recorded the dose of each drug given, and whether the dose used was the target dose established in clinical trials. In patients who did not receive these drugs and in those who did not attain the target dose, the reasons for these circumstances were analyzed.

The ESC Heart Failure Long-Term Registry has a quality assurance program that includes audits in around $10 \%$ of the participating centers, selected randomly. Two Spanish centers were audited in 2013.

The study was approved by the ethics committee of each center, and all patients gave informed consent for their inclusion.

\section{Statistical Analysis}

The results for continuous variables are expressed as the median [first and third quartile] and the results for categorical variables as percentages. The analyses were performed centrally by support staff of the EORP Department of the European Heart House using SAS software (SAS Institute, Inc.; Cary, North Carolina, United States).

\section{RESULTS}

The results presented correspond to 2834 ambulatory patients (chronic HF group) recorded from Spanish centers. The results from the group of hospitalized patients ( $n=702$ in Spain) are not included because the guideline recommendations for this population are based on a low level of evidence. The 27 hospitals participating in Spain included centers providing different levels of care: 19 centers offered the full range of cardiologic services, including interventional procedures (catheterization, cardiac resynchronization, defibrillator implantation) and cardiac surgery (in Spain, most of these centers also perform heart transplants); 4 centers provided interventional procedures, but not cardiac surgery; and 4 centers had cardiology units but did not carry out cardiac interventional procedures or cardiac surgery.

\section{General Characteristics}

The patients' characteristics are summarized in Table 1. Patients included in the study were relatively young (half younger than 65 years), predominantly male, and only 1 of 4 patients had preserved EF (> $45 \%)$. 
Table 1. Baseline Patient Characteristics

\begin{tabular}{|c|c|}
\hline & $\mathrm{CHF}^{*}$ \\
\hline Patients, No. & 2834 \\
\hline Age, years & $65[56-73]$ \\
\hline Women & 28.5 \\
\hline BMI & $28[25-31]$ \\
\hline $\mathrm{SBP}, \mathrm{mmHg}$ & 120 [110-134] \\
\hline $\mathrm{SBP} \leq 110 \mathrm{mmHg}$ & 32.7 \\
\hline HR, bpm & $70[60-76]$ \\
\hline $\mathrm{HR} \geq 70, \mathrm{bpm}$ & 50.2 \\
\hline $\mathrm{EF}, \%$ & $35[28-46]$ \\
\hline $\mathrm{EF}>45 \%$ & 25.4 \\
\hline NYHA functional class III-IV & 17.0 \\
\hline Pulmonary or peripheral congestion & 51.7 \\
\hline Third heart sound & 2.9 \\
\hline Peripheral/cold hypoperfusion & 2.0 \\
\hline Mitral regurgitation & 13.3 \\
\hline Aortic stenosis & 3.1 \\
\hline Previous hospitalization & 51.4 \\
\hline HF diagnosis $>12$ months & 63.4 \\
\hline Ischemic cause & 38.5 \\
\hline Atrial fibrillation & 33.6 \\
\hline Diabetes mellitus & 35.1 \\
\hline Peripheral arterial disease & 12.1 \\
\hline Hypertension & 55.9 \\
\hline COPD & 14.8 \\
\hline Sleep apnea & 8.3 \\
\hline Stroke/TIA & 8.3 \\
\hline Renal dysfunction & 15.7 \\
\hline Hepatic dysfunction & 2.5 \\
\hline Depression & 9.0 \\
\hline Pacemaker & 6.0 \\
\hline
\end{tabular}

BMI, body mass index; $\mathrm{CHF}$, chronic heart failure; COPD, chronic obstructive pulmonary disease; $\mathrm{EF}$, ejection fraction; $\mathrm{HF}$, heart failure; HR, heart rate; NYHA: New York Heart Association functional class; SBP, systolic blood pressure; TIA, transient ischemic attack.

Unless otherwise indicated, the values express the percentage or the median [first and third quartile].

* Ambulatory patients.

\section{Pharmacological Treatment in Ambulatory Patients}

Angiotensin converting enzime inhibitors/ARB were prescribed in $86.8 \%$ of ambulatory patients, beta-blockers (BB) in $88.7 \%$, and MRA in $63.8 \%$ (Table 2). In patients with low EF (EF $\leq 40 \%$ or $\leq 35 \%$ for MRA), which is the profile of patients deemed suitable to receive these treatments in the 2012 ESC guidelines, ACEI/ARB were prescribed in $92.6 \%$, BB in $93.3 \%$, and MRA in $74.5 \%$. Furthermore, $65.4 \%$ (795/1.216) of patients with $\mathrm{EF} \leq 35 \%$ were prescribed all 3 types of drugs (ACEI/ARB, BB, and MRA). 
Table 2. Pharmacological Treatment in Ambulatory Patients with Heart Failure

\begin{tabular}{|c|c|c|c|}
\hline Treatments & $\begin{array}{l}\text { Total population } \\
\qquad(\mathrm{n}=2409)\end{array}$ & $\begin{array}{c}\text { Low EF }{ }^{a} \\
(\leq 40 \%)(n=1526)\end{array}$ & $\begin{array}{c}\text { Preserved EF } \\
(>40 \%)(\mathrm{n}=883)\end{array}$ \\
\hline$A C E I / A R B$ & 86.8 & 92.6 & 76.8 \\
\hline$A C E I$ & 58.7 & 64.6 & 48.5 \\
\hline Ramipril $^{\mathrm{b}}$ & 40.6 & 42.9 & 35.3 \\
\hline Enalapril $^{\mathrm{b}}$ & 51.4 & 49.1 & 56.5 \\
\hline Perindopril $^{\mathrm{b}}$ & 1.1 & 0.4 & 2.8 \\
\hline Beta-blockers & 88.7 & 93.3 & 80.9 \\
\hline Carvedilol $^{\mathrm{b}}$ & 52.3 & 55.0 & 46.9 \\
\hline Bisoprolol $^{\mathrm{b}}$ & 37.4 & 36.3 & 39.6 \\
\hline Metoprolol $^{\mathrm{b}}$ & 1.0 & 0.9 & 1.3 \\
\hline$A R B$ & 28.9 & 29.1 & 28.5 \\
\hline Candesartan ${ }^{\mathrm{b}}$ & 32.0 & 35.1 & 26.6 \\
\hline $\operatorname{Losartan}^{\mathrm{b}}$ & 30.5 & 31.1 & 29.4 \\
\hline Valsartan ${ }^{\mathrm{b}}$ & 23.6 & 22.8 & 25.0 \\
\hline$M R A^{\mathrm{a}}$ & 63.8 & 74.5 & 52.9 \\
\hline Spironolactone ${ }^{\mathrm{b}}$ & 50.0 & 47.6 & 53.4 \\
\hline Eplerenone $^{\mathrm{b}}$ & 49.6 & 52.2 & 45.8 \\
\hline Canrenone $^{\mathrm{b}}$ & 0.1 & 0.1 & 0.0 \\
\hline Diuretics & 78.5 & 83.3 & 70.1 \\
\hline Digitalis & 20.3 & 22.0 & 17.3 \\
\hline Statins & 62.4 & 66.7 & 54.8 \\
\hline Antiplatelet agents & 43.3 & 48.6 & 34.3 \\
\hline Oral anticoagulants & 42.6 & 41.9 & 43.7 \\
\hline Amiodarone & 10.2 & 11.3 & 8.3 \\
\hline Ivabradine $^{\mathrm{a}}$ & 14.5 & 19.7 & 9.2 \\
\hline Nitrates & 15.7 & 16.8 & 13.6 \\
\hline Calcium channel blockers & 8.8 & 5.6 & 14.5 \\
\hline
\end{tabular}

ACEI, angiotensin converting enzyme inhibitors; ARB, angiotensin receptor blockers; MRA, mineralocorticoid receptor antagonists; EF, ejection fraction. Data are expressed as percentage.

${ }^{a}$ In the case of mineralocorticoid receptor antagonists and ivabradine, the low and preserved ejection fraction groups are ejection fraction $\leq 35 \%(n=1216)$ and ejection fraction $>35 \%(n=1193)$

${ }^{\mathrm{b}}$ Percentage of the total taking any of the drugs of the corresponding group.

As to ivabradine, $70.9 \%$ of ambulatory patients (249/351) with sinus rhythm, EF $\leq 35 \%$, and heart rate $\geq 70 \mathrm{bpm}$ did not receive ivabradine, and in this same subgroup, only $21.6 \%$ of patients $(76 / 351)$ were prescribed all 4 types of drugs (ACEI/ARB, BB, MRA, and ivabradine).

In a large proportion of the patients not prescribed the treatments recommended in the guidelines (ACEI/ARB, BB, and MRA), there was a justification for doing so. The distribution of ambulatory patients with low EF $(\leq 40 \%)$ according to whether or not they received each of the 3 main drug classes is shown in Figure 1, and in those who did not receive these drugs, the reasons for not doing so are listed. In patients who were not prescribed each of the treatments, the true underprescription rates - that is, the percentage of patients not prescribed a treatment and with no recorded justification-were $3.4 \%$ for ACEI/ARB, $1.8 \%$ for BB, and $19.0 \%$ for MRA. 


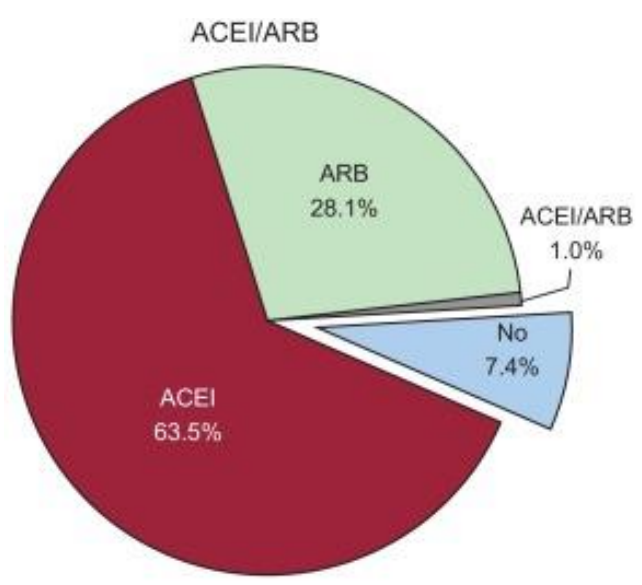

$n=1526$

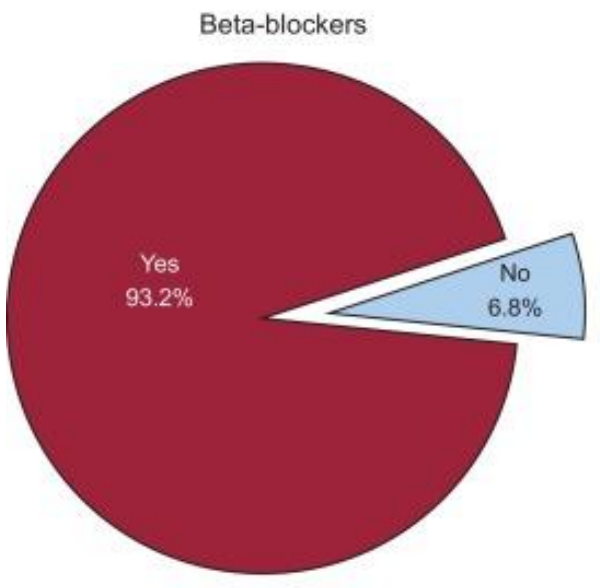

$n=1526$

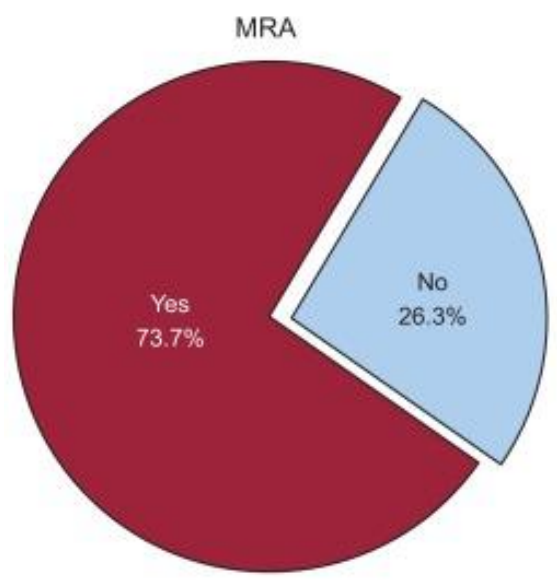

$n=1526$

\begin{tabular}{|lr|}
\hline Contraindicated & $(\mathrm{n}=22 ; 1.4 \%)$ \\
- Severe renal dysfunction & $(\mathrm{n}=17 ; 77.3 \%)$ \\
- Symptomatic hypotension & $(\mathrm{n}=1 ; 4.6 \%)$ \\
- Hyperkalemia & $(\mathrm{n}=3 ; 13.6 \%)$ \\
- Other & $(\mathrm{n}=1 ; 4.6 \%)$ \\
\hline
\end{tabular}

\begin{tabular}{|lr|}
\hline Not tolerated & $(n=39 ; 2.6 \%)$ \\
- Worsening of renal function & $(n=4 ; 10.3 \%)$ \\
- Symptomatic hypotension & $(n=31 ; 79.5 \%)$ \\
- Hyperkalemia & $(n=1 ; 2.6 \%)$ \\
- Angioedema & $(n=0 ; 0.0 \%)$ \\
- Other & $(n=3 ; 7.7 \%)$ \\
\hline
\end{tabular}

True undertreatment

$(n=52 ; 3.4 \%)$

\begin{tabular}{lr}
\hline Contraindicated & $(n=11 ; 0.7 \%)$ \\
- Asthma/COPD & $(n=2 ; 18.2 \%)$ \\
- Bradyarrhythmia & $(n=3 ; 27.3 \%)$ \\
- Symptomatic hypotension & $(n=1 ; 9.1 \%)$ \\
- Other & $(n=5 ; 45.4 \%)$ \\
\hline
\end{tabular}

\begin{tabular}{|lr|}
\hline Not tolerated & $(n=65 ; 4.3 \%)$ \\
- Bronchospasm & $(n=13 ; 20.0 \%)$ \\
- Worsening of renal function & $(n=1 ; 1.5 \%)$ \\
- Symptomatic hypotension & $(n=22 ; 33.9 \%)$ \\
- Bradyarrhythmia & $(n=8 ; 12.3 \%)$ \\
- Worsening of HF & $(n=8 ; 12.3 \%)$ \\
- Sexual dysfunction & $(n=1 ; 1.5 \%)$ \\
- Other & $(n=12 ; 18.5 \%)$ \\
\hline
\end{tabular}

True undertreatment

( $n=27 ; 1.8 \%$ )

\begin{tabular}{|lr|}
\hline Contraindicated & $(\mathrm{n}=72 ; 4.7 \%)$ \\
- Hyperkalemia & $(\mathrm{n}=21 ; 29.2 \%)$ \\
- Renal dysfunction & $(\mathrm{n}=49 ; 68.1 \%)$ \\
- Other & $(\mathrm{n}=2 ; 2.8 \%)$ \\
\hline & $(\mathrm{n}=39 ; 2.6 \%)$ \\
\hline $\begin{array}{l}\text { Not tolerated } \\
\text { - Hyperkalemia }\end{array}$ & $(\mathrm{n}=13 ; 33.3 \%)$ \\
- Worsening of renal dysfunction & $(\mathrm{n}=13 ; 33.3 \%)$ \\
- Gynecomastia & $(\mathrm{n}=0 ; 0.0 \%)$ \\
- Other & $(\mathrm{n}=13 ; 33.3 \%)$ \\
\hline
\end{tabular}

True undertreatment

$(n=290 ; 19.0 \%)$

Figure 1. Reason why recommended treatments were not used in patients $(n=1526)$ with low ejection fraction $(\leq 40 \%)$. ARB, angiotensin receptor blockers; ACEI, angiotensin converting enzyme inhibitors; MRA, mineralocorticoid receptor antagonists; COPD, chronic obstructive pulmonary disease; HF, heart failure. 
Only a small percentage of ambulatory patients with a low EF reached the target doses reported in clinical trials using these drugs: $16.2 \%$ of those receiving ACEI, 23.3\% of those with ARB, $13.2 \%$ of patients with $\mathrm{BB}$, and $23.5 \%$ of patients receiving MRA (Table 3). There was often a clinical reason indicating that the dose prescribed was optimal for the patient, but in at least 1 of 4 patients ( 1 of 2 in the case of MRA), no justification was recorded.

Table 3. Attainment of the Target Dose in Recommended Treatments for Ambulatory Patients With Low Ejection Fraction

\begin{tabular}{|c|c|c|c|c|}
\hline & $\begin{array}{l}\text { Achieved target } \\
\text { dose }\end{array}$ & $\begin{array}{l}\text { Did not achieve } \\
\text { target dose }\end{array}$ & \multicolumn{2}{|c|}{ Reason for not achieving target dose } \\
\hline \multirow[t]{7}{*}{ ACEI (977 patients) } & $158(16.2)$ & $819(83.8)$ & Still in drug titration phase & $248(30.3)$ \\
\hline & & & Symptomatic hypotension & $254(31.0)$ \\
\hline & & & Worsening of renal function & $48(5.9)$ \\
\hline & & & Hyperkalemia & $37(4.5)$ \\
\hline & & & Cough & $3(0.4)$ \\
\hline & & & Angioedema & $1(0.1)$ \\
\hline & & & Others/unknown & $228(27.8)$ \\
\hline \multirow[t]{6}{*}{ ARB (395 patients) } & $92(23.3)$ & $303(76.7)$ & Still in drug titration phase & $91(30.0)$ \\
\hline & & & Symptomatic hypotension & $97(32.0)$ \\
\hline & & & Worsening of renal function & $27(8.9)$ \\
\hline & & & Hyperkalemia & $8(2.6)$ \\
\hline & & & Angioedema & $2(0.7)$ \\
\hline & & & Others/unknown & $78(25.7)$ \\
\hline \multirow[t]{8}{*}{$\begin{array}{l}\text { Beta-blockers (1413 } \\
\text { patients) }\end{array}$} & $186(13.2)$ & $1227(86.8)$ & Still in drug titration phase & $425(34.6)$ \\
\hline & & & Symptomatic hypotension & $240(19.6)$ \\
\hline & & & Bradyarrhythmia & $111(9.0)$ \\
\hline & & & Worsening of HF & $39(3.2)$ \\
\hline & & & Bronchospasm & $33(2.7)$ \\
\hline & & & Worsening of PAD & $22(1.8)$ \\
\hline & & & Sexual dysfunction & $7(0.6)$ \\
\hline & & & Others/unknown & $350(28.5)$ \\
\hline \multirow[t]{5}{*}{ MRA (905 patients) } & $213(23.5)$ & $692(76.5)$ & Still in drug titration phase & $185(26.7)$ \\
\hline & & & Hyperkalemia & $72(10.4)$ \\
\hline & & & Worsening of sexual dysfunction & $84(12.1)$ \\
\hline & & & Gynecomastia & $4(0.6)$ \\
\hline & & & Others/unknown & $347(50.1)$ \\
\hline
\end{tabular}

ACEI, angiotensin converting enzyme inhibitors; ARB, angiotensin receptor blockers; HF, heart failure; MRA, mineralocorticoid receptor antagonists; PAD, peripheral arterial disease. Data are expressed as No. (\%).

\section{Device Use in Ambulatory Patients}

Figure 2 shows the distribution of ambulatory patients according to whether or not they had an indication for defibrillator implantation or cardiac resynchronization therapy, whether they already had a device, and the reasons why they did not have a device despite having an indication for one. In total, $64.0 \%$ of patients did not fulfill the guidelines' criteria for defibrillator implantation and $80.4 \%$ did not meet the criteria for cardiac resynchronization therapy. Among patients with criteria for defibrillation, $78 \%$ (788 of 1016) already had defibrillators and an additional $12 \%$ were in the planning process for defibrillator implantation. In patients with an indication for resynchronization therapy, 74\% (406 of 549) already had a pacemaker and 14\% (76 of 549) were in the planning process. In patients who met the criteria but were not considered for device implantation (10\% for defibrillators and $12 \%$ for resynchronization), the main reason for this circumstance was uncertainty about the indication. 


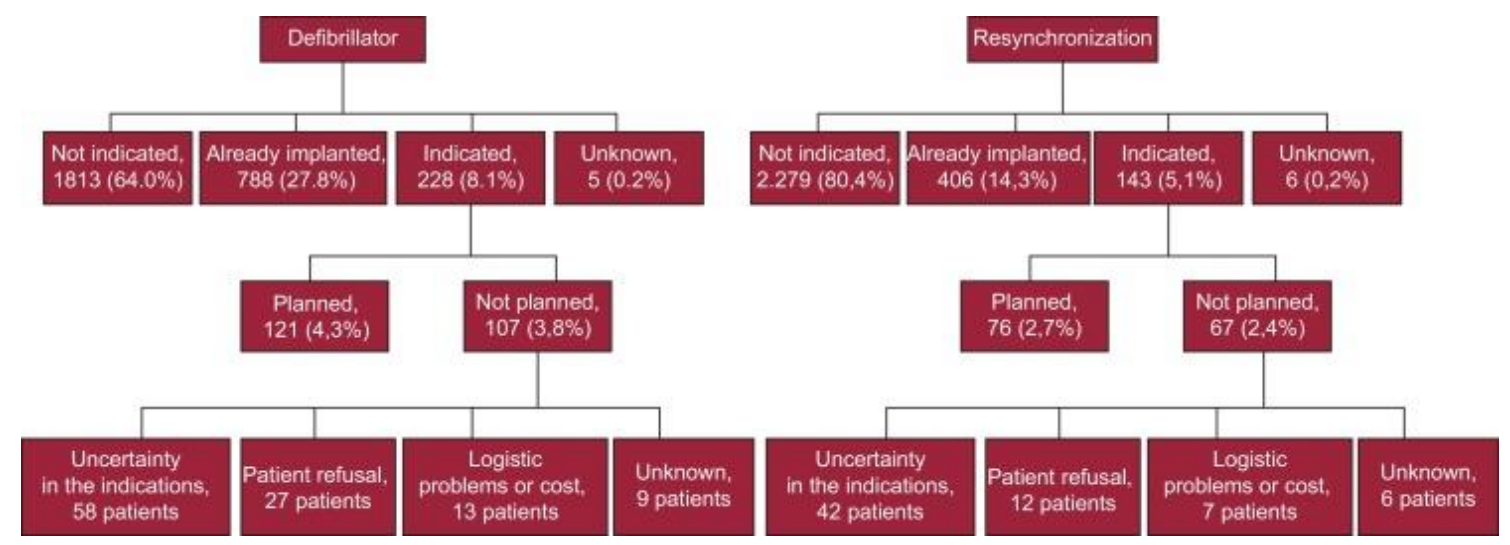

Figure 2. Automated defibrillator implantation rates, cardiac resynchronization therapy rates, and reasons why ambulatory patients did not receive these treatments $(n=2834)$.

\section{DISCUSSION}

This study brings to light the focus of HF treatment on meeting the requirements of individual patients. Furthermore, it shows that simple calculation of the percentage of treated patients may not be an appropriate measure to indicate the quality of the healthcare provided in a specific condition. Compared with previous reports, this study has the added value of careful, comprehensive collection of the treatments and doses administered in the population examined, as well as the reasons why indicated drugs were not prescribed or the doses given did not reach the targets defined in clinical studies. A previous estimation from the European Heart Failure Pilot Survey, ESC-HF Pilot, ${ }^{11}$ which described only the number of patients treated, reported administration of ACEI/ARB, BB, and MRA in $88.5 \%, 86.7 \%$, and $43.7 \%$ of patients, respectively. In contrast, when justified reasons for not prescribing a certain treatment were taken into account, we found that the true problem of undertreatment in Spain is practically inconsequential with regard to ACEI/ARB and BB (3.4\% and $1.8 \%)$, whereas there is still a wide margin for improvement in MRA prescription (true undertreatment in 19.0\%).

Another observation highlighted by this study has important implications for clinical practice. We found that compliance with the guidelines regarding treatment indications has improved considerably compared with the situation 10 years ago. At that time, Spain showed the lowest use of BB and ACEI (around $10 \%$ and $40 \%$, respectively) among all the participating European countries, ${ }^{12}$ whereas the current prescription of recommended HF treatments is excellent (with the possible exception of MRA). Nonetheless, this improvement was not seen in attainment of the doses defined in clinical trials, as most patients did not receive the target doses of the treatments indicated. In a large percentage of these patients, there was a sound reason for this situation: dosing was in the adjustment phase or there were toxicity symptoms indicating that the maximum dose tolerated had been reached. Therefore, many of these patients were actually receiving their optimal dose; that is, the maximum "possible dose" even though it may not have been the "target dose". Despite these findings, in 1 of every 4 patients ( 1 of 2 in the case of MRA), no reason was given for the lower doses. These percentages should be considered the worst-case scenario according to the available information. Even in a high-quality registry carried out meticulously, the reasons for lower dosing might not be available to the person collecting this information in each center because of the nature of the HF treatment process (performed by several professionals over time, working in different settings). Another factor that could have made a substantial contribution to the gap between our results and the target doses is the difficulty of establishing rigorous programs for dose titration of HF drugs. Dose adjustment implies numerous visits and laboratory analyses to carefully tailor the treatment to the patient's requirements. It would be of particular value if our patients could be attended when and where they need these visits, and not simply according to the availability of regular care, which is necessarily restricted. This is a limitation that hinders proper use of our therapeutic resources and it underscores the need to establish integrated programs that go beyond the hospital setting and include health professionals of several types (eg, specialized physicians in the hospital and community, specialized nurses). ${ }^{13}$ 
This study has an advantage over other registries in Spain, some of them quite recent, ${ }^{4,14,15}$ in that it allows direct comparison with other data in the European registry, of which it forms a part. All contributors to this cornerstone project of the ESC use identical methods. Furthermore, it is an active registry that continues to include patients and their follow-up. The situation regarding the true undertreatment rates in Spain is virtually the same as that reported for the overall European study ${ }^{8}$ (including Spanish centers). However, although the percentage of patients reaching the target doses established in clinical trials is rather low throughout Europe, it is slightly lower in Spain. ${ }^{3}$

As to the more recently available HF drugs such as ivabradine, it seems that their incorporation has been faster in Spain than in Europe as a whole, in both patients with low EF (19.7\% vs 10.5\%) and in the overall cohort of ambulatory patients $(14.5 \%$ vs $8.5 \%) .^{8}$ Of note, however, in the subanalysis of ivabradine use in Spain, low EF was defined as $\leq 35 \%$, whereas in the overall European analysis it was $\leq$ $45 \% .^{8}$ In a Spanish study in ambulatory patients conducted approximately 1 year before these results, only $7.2 \%$ of patients received this drug. ${ }^{16}$ Despite the current improvement, the percentage of patients in Spain who meet the criteria for ivabradine treatment but are not prescribed this drug remains high: only $29.1 \%$ of ambulatory patients with sinus rhythm, $\mathrm{EF} \leq 35 \%$, and heart rate $\geq 70 \mathrm{bpm}$ received this medication, again reflecting the delay between demonstration of the benefits of a specific intervention and its incorporation into clinical practice. This aspect should be reassessed in the future. In contrast to other drugs, ivabradine was incorporated for the first time in the 2012 guidelines, which were published at the same time as the start of data collection for the registry in Spain. Information on adherence to the guidelines for this medication throughout Europe has not yet been published, which prevents direct comparison in the subgroup of patients in whom the guidelines recommend its use.

As regards device use, it seems that the reasons why patients with indications for these devices did not receive them are not exclusively economic, despite the economic crisis. It is possible that physicians themselves may be managing resource use while keeping in mind the existing economic difficulties, but this would have very different implications than if devices were not being implanted for purely economic reasons.

\section{Limitations}

Some of the potential limitations of this study have been mentioned in other sections of the discussion. The main limitation is that with the available data it is impossible to assure that case recording was complete in all the participating Spanish centers. Some hospitals included fewer patients than others of the same size and care level, although this occurred in very few centers. Huge efforts have been made to simplify the protocol and improve the possibility of including all consecutive patients seen on the registry days. Although complete recording has not been confirmed in all centers, the audits performed in 2 Spanish hospitals indicated good compliance with the study protocol (unpublished data, personal report from the EORP staff). As a reflection that case recording was good in our centers, Spain was the country with the largest number of patients included in the registry among all participants. Another possible limitation lies in the procedure for selecting participating centers, which was not done randomly. Among the centers interested in participating, a larger number of tertiary-level hospitals were included than those recommended by the protocol, ${ }^{11}$ which resulted in the participation of fewer lower-level centers. This reflects the organization of HF care in Spain: lower-level centers may not have HF units, and care for these patients is often delegated to internal medicine specialists rather than cardiologists, who mainly perform complementary testing. We believe that the final list reflects the varying profile of Spanish centers in which cardiologists are responsible for the care of HF patients and that it is geographically representative, in case this factor might be important in the estimations made. The design of the database and the software for data entry, which, for example, had online information about recommended dosing, guarantee high-quality data and enable examination of aspects that have not been thoroughly investigated to date, such as the reasons why target doses were not reached.

In summary, after taking into consideration justified reasons for not prescribing drugs to patients with low EF, compliance with the guidelines was excellent in Spain. Simple estimation of the percentage of patients treated is a poor quality indicator of HF care. The focus should be changed from emphasis on the indications for treatments to the introduction of measures that will improve the attainment of optimal doses for each patient (taking into account the maximum tolerated dose according to clinical, hemodynamic, and/or toxicity-related factors). The continuous updating of the registry makes it a magnificent instrument for monitoring HF treatment in Spain and enables comparison with the situation 
in the rest of Europe in order to identify strengths and weaknesses ${ }^{17}$ and design improvements where necessary.

\section{CONFLICTS OF INTEREST}

None declared.

\section{ACKNOWLEDGEMENTS}

Many of the participating investigators and centers are part of the Cardiovascular Research Network of Carlos III Institute of Health (Red de Investigación Cardiovascular [RIC] of the Instituto de Salud Carlos III).

Servier España contributed unconditional grant funding for the development of the registry in Spain through an agreement with the Heart Failure and Cardiac Transplantation Section of the Spanish Society of Cardiology.

We thank Javier Muñiz for his contribution in writing the first drafts of the manuscript.

We are grateful to the following members of the European Heart House EORP: Cecile Laroche (statistical analysis), Gerard Gracia (data monitor), Emanuela Fiorucci (project head), Aldo P. Maggioni (scientific coordinator), and Thierry Ferreira (head of department).

\section{Appendix. List of Spanish Centers and the Investigators, by Provinces}

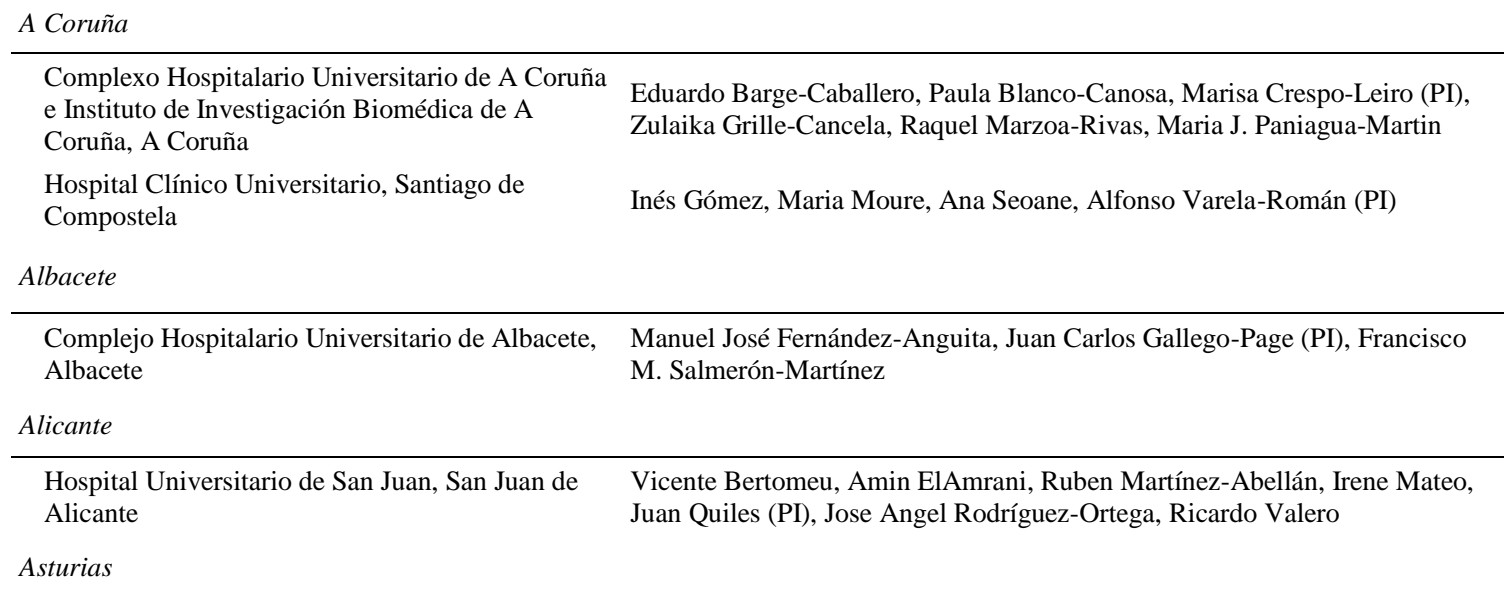

Hospital Universitario Central de Asturias, Oviedo Beatriz Díaz-Molina (PI), Elena Díaz-Velasco, José Luis Lambert-Rodríguez Barcelona

\begin{tabular}{ll}
\hline $\begin{array}{l}\text { Hospital de Sabadell, Sabadell } \\
\text { Hospital Universitario Germans Trias i Pujol, } \\
\text { Badalona }\end{array}$ & Francisco Epelde-Gonzalo (PI), Josefina Orus \\
$\begin{array}{l}\text { Hospital de la Santa Creu i Sant Pau, Barcelona } \\
\text { Hospital Universistari de Bellvitge, L'Hospitalet de }\end{array}$ & $\begin{array}{l}\text { Lola García-Cosío, Ana Méndez, Sonia Mirabet, Eulàlia Roig (PI) } \\
\text { Muntané }\end{array}$ \\
$\begin{array}{ll}\text { Llobregat } \\
\text { Granada }\end{array}$ & $\begin{array}{l}\text { Vicente Alcade-Martínez, Marta Fernández-Álvarez, Silvia López-Fernández } \\
\text { (PI), Monserrat Puga-Martínez, Ricardo Rivera-López, Jose Luis Serrano- }\end{array}$ \\
\hline $\begin{array}{l}\text { Hospital Universitario Virgen de las Nieves, } \\
\text { Granada }\end{array}$ & Martínez \\
Balearic Islands & \\
\hline Hospital Manacor, Mallorca & Bernardo García-de la Villa, Ana Sahuquillo (PI)
\end{tabular}


Hospital de Cantoblanco, Madrid

Hospital Universitario Puerta de Hierro,

Hospital Universitario 12 de Octubre, Madrid Majadahonda

Andrea Araujo, Almudena Castro-Conde, Regina Dalmau González-Gallarza (PI), Angel Manuel Iniesta-Manjavacas, Sandra Ofelia Rosillo, Oscar Salvador-Montanés

Luis Alonso-Pulpón, Ana Briceno, Marta Cobo-Marcos, Pablo García-Pavia, Manuel Gómez-Bueno, Ariadna González-Segovia, Inés Sayago, Javier Segovia-Cubero (PI), Teresa Soria

Elvira Barrios Garrido-Lestache, Juan F. Delgado-Jiménez (PI), Pilar Escribano-Subías, Miguel Angel Gómez-Sánchez, Maria José Ruiz-Cano, Maria Vicente-Hernández

Málaga

Hospital Costa del Sol, Marbella

Rafael Bravo-Marqués, Francisco Torres-Calvo (PI)

Hospital Regional Universitario Carlos Haya, Málaga

Manuel de Mora-Martín (PI), Ana García-Bellón, Ana González-González, Jose Maria Pérez-Ruiz, Beatriz Pérez-Villardón

Hospital Universitario Virgen de la Victoria, Málaga

Jose Manuel García-Pinilla (PI)

Murcia

Hospital Universitario Virgen de la Arrixaca, El Palmar

Iris P. Garrido-Bravo, María Rosario Gracia-Rodenas, Domingo A. PascualFigal (PI), Francisco Pastor-Pérez, Maria Teresa Pérez-Martínez

Pontevedra

Hospital Povisa, Vigo Juan Carlos Arias (PI)

Santa Cruz de Tenerife

Hospital Universitario de Canarias, La Laguna Idaira Famara Hernández-Baldomero, Antonio Lara-Padrón (PI), Ignacio Laynez-Cerdena

Seville

Hospital Universitario Virgen Macarena, Seville Carla Fernández-Vivancos (PI)

Tarragona

Hospital de Tortosa Verge de la Cinta, Tortosa

David Bierge-Valero (PI)

Valencia

Consorcio Hospital General Universitario de

Valencia, Valencia

Lorenzo Fácila-Rubio, David García-Escriva, Pilar García-González, Angel

Pellicer-Cabo, Jose Pérez-Silvestre, Francisco Ridocci-Soriano (PI)

Hospital Universitari i Politècnic La Fe, Valencia

Luis Almenar-Bonet (PI), Elena Marqués-Sule, Ignacio J. Sánchez-Lázaro

Valladolid

Hospital Clínico Universitario de Valladolid, Valladolid

Luis de la Fuente-Galán (PI), Javier López-Díaz, Amada Recio-Platero

Vizcaya

Hospital San Eloy, Barakaldo

Javier Andrés (PI)

Zaragoza

Hospital Universitario Miguel Servet, Zaragoza

Carmen Aured-Guallar, Teresa Blasco-Peiró, Ana Portolés-Ocampo, Ester Sánchez-Insa, Marisa Sanz Julve (PI) 


\section{References}

1. Sayago-Silva, F. García-López, J. Segovia-CuberoEpidemiología de la insuficiencia cardiaca en España en los últimos 20 añosRev Esp Cardiol., 66 (2013), pp. 649-656

2. K. Swedberg, M. Komajda, M. Böhm, J.S. Borer, I. Ford, A. Dubost-Brama, et al.Ivabradine and outcomes in chronic heart failure (SHIFT): a randomized placebo-controlled studyLancet., 376 (2010), pp. 875-885

3. J.J. McMurray, S. Adamopoulos, S.D. Anker, A. Auricchio, M. Bohm, K. Dickstein, et al.ESC Guidelines for the diagnosis and treatment of acute and chronic heart failure 2012: The Task Force for the Diagnosis and Treatment of Acute and Chronic Heart Failure 2012 of the European Society of Cardiology. Developed in collaboration with the Heart Failure Association (HFA) of the ESCEur J Heart Fail., 14 (2012), pp. 803-869

A. García Castelo, J. Muñiz García, P. Sesma Sánchez, A. Castro Beiras, grupo de estudio INCARGALUtilización de recursos diagnósticos y terapéuticos en pacientes ingresados por insuficiencia cardíaca: influencia del servicio de ingreso (estudio INCARGAL)Rev Esp Cardiol., 56 (2003), pp. 49-56

4. Mosquera Pérez, J. Muñiz García, E. Freire Castroseiros, A. García Castelo, A. Castro Beiras, grupo de trabajo del estudio INCARGALUso de anticoagulación al alta hospitalaria en pacientes con insuficiencia cardíaca y fibrilación auricularRev Esp Cardiol., 56 (2003), pp. 880-887

5. J. Muñiz García, J.J. Gómez Doblas, M.I. Santiago Pérez, E. De Teresa Galván, J.M. Cruz Fernández, A. Castro Beiras, Grupo de Trabajo del Proyecto CAMEfecto de un programa sencillo de educación de los profesionales en el cumplimiento de medidas de prevención secundaria en el momento del alta hospitalaria tras un síndrome coronario agudo. Proyecto CAMRev Esp Cardiol., 57 (2004), pp. 1017-1028

6. J.I. Vidal Pardo, T.R. Pérez Castro, X.L. López Álvarez, F.J. García Soidán, M.I. Santiago Pérez, J. MuñizQuality of care of patients with type-2 diabetes in Galicia (NW Spain) [OBTEDIGA project]Int J Clin Pract., 65 (2011), pp. 1067-1075

7. A.P. Maggioni, S.D. Anker, U. Dahlstrom, G. Filippatos, P. Ponikowski, F. Zannad, et al., Heart Failure Association of the ESC (HFA)Are hospitalized or ambulatory patients with heart failure treated in accordance with European Society of Cardiology guidelines? Evidence from 12440 patients of the ESC Heart Failure LongTerm RegistryEur J Heart Fail., 15 (2013), pp. 1173-1184

8. K. Dickstein, A. Cohen-Solal, G. Filippatos, J.J. McMurray, P. Ponikowski, P.A. Poole-Wilson, et al.ESC Guidelines for the diagnosis and treatment of acute and chronic heart failure 2008: the Task Force for the Diagnosis and Treatment of Acute and Chronic Heart Failure 2008 of the European Society of Cardiology. Developed in collaboration with the Heart Failure Association of the ESC (HFA) and endorsed by the European Society of Intensive Care Medicine (ESICM)Eur Heart J., 29 (2008), pp. 2388-2442

9. R. FerrariEURObservational Research ProgrammeEur Heart J., 31 (2010), pp. 1023-1031

10. A.P. Maggioni, U. Dahlström, G. Filippatos, O. Chioncel, M.C. Leiro, J. Drozdz, et al.EURObservational Research Programme: the Heart Failure Pilot Survey (ESC-HF Pilot)Eur J Heart Fail., 12 (2010), pp. 1076-1084

11. M.A. Komajda, F. Follath, K. Swedberg, J. Cleland, J.C. Aguilar, A. Cohen-Solal, et al., The Study Group of Diagnosis of the Working Group on Heart Failure of the European Society of CardiologyThe EuroHeart Failure Survey programme: a survey on the quality of care among patients with heart failure in EuropeEur Heart J., 24 (2003), pp. 464-474

12. Abel-Diéguez V, Amado-Aller C, Bahamonde-Sánchez M, Bouza-Álvarez D, Castro Beiras A, Crespo Leiro M, et al. Proceso de mejora de la asistencia a la insuficiencia cardiaca en el Área Sanitaria (PROMICAS). Premios Profesor Barea. 10. ${ }^{\text {e ed. }} 2012$ [citado 9 Oct 2014]. Disponible en: http://www.fundacionsigno.com/archivos/publicaciones/2012-10-PPB-modalidad-3-Accesit.pdf

13. M. AnguitaCaracterísticas clínicas, tratamiento y morbimortalidad a corto plazo de pacientes con insuficiencia cardiaca controlados en consultas específicas de insuficiencia cardiaca. Resultados del Registro BADAPICRev Esp Cardiol., 57 (2004), pp. 1159-1169

A. González-García, M. Montero Pérez-Barquero, F. Formiga, J.R. González-Juanatey, M.A. Quesada, F. Epelde, et al. ¿Se ha incrementado el uso de bloqueadores beta en pacientes con insuficiencia cardiaca en medicina interna? Implicaciones pronósticas: registro RICARev Esp Cardiol., 67 (2014), pp. 196-202

14. M. Anguita, J. Comin-Colet, F. Formiga, L. Almenar, M. Crespo-Leiro, L. ManzanoTratamiento de la insuficiencia cardiaca con función sistólica deprimida: situación actual en España. Resultados del estudio VIDAICRev Esp Cardiol., 67 (2014), pp. 769-770

15. P.M. Seferovic, S. Stoerk, G. Filippatos, V. Mareev, A. Kavoliuniene, A.D. Ristic, et al. Organization of heart failure management in European Society of Cardiology member countries: survey of the Heart Failure Association of the European Society of Cardiology in collaboration with the Heart Failure National Societies/Working GroupsEur J Heart Fail., 15 (2013), pp. 947-959 